\title{
Research on Credibility of Online Word of Mouth of Apparel
}

\author{
Kui Yu \\ School of Business Management, Donghua University \\ Shanghai, China \\ yukui@dhu.edu.cn
}

\begin{abstract}
Key words: apparel commodity; online word of mouth; credibility
\end{abstract}
\begin{abstract}
Internet features interactive, anonymity, and personalization, which have been changing people's habit. Many apparel commodity and consumers are both exposing to the Internet, giving comments, sharing information, obtaining resources. Based on reviewing relevant literature, this paper is aimed to take research on what factors impact online word-of-mouth credibility of apparel. Here are the conclusions: 1.Online word-of-mouth source credibility has positive impact on online word-of-mouth credulity of apparel; 2.Online word-of-mouth communication has positive impact on word-of-mouth credibility of apparel; 3.Receiver's factor has positive impact on online word-of-mouth credibility of apparel.
\end{abstract}

\section{Introduction}

The "Survey on 2014 China online shopping market" released by CNNIC shows that the scale of China's online shoppers has reached up to 361 million, increasing 59.53 million year-on-year by 19.7 percent. At the same time, according to the latest data of iResearch, 2015 China's online shopping transactions has reached RMB872.54billion, year-on-year up by $39.6 \%$, roughly equivalent to $10.7 \%$ of total retailing sales of social consumer goods. According to the survey of CNNIC2014, China netizen is at a better level of perception and application. $48.6 \%$ of the netizen agree the network environment in China is safer or very safe; $54.5 \%$ express their trust toward the online information; $60.0 \%$ hold a positive attitude toward online sharing; $43.8 \%$ prefer making comment online, $53.1 \%$ think they are more or most pro to rely on the Internet. Data from CNNIC shows in 2014 the most fundamental factor that influences consumer purchasing decision is the online word of mouth(WOM) of the product, accounting for $71.1 \%$ of respondents; followed by the reputation of the website or retailer, accounting for $62.3 \%$. In terms of online shopping category, apparel is still the domestic and overseas major one. Its online consumers account for $75.3 \%$ of the overall netizen, approximately equal to that of 2013. As a result of high gross margin and high repetition rate, apparel has been the main source of profit for online retailers, attracting a large number of online retailers to actively get involved in exploring this market. The paper is aimed to analyze the factors impacting online WOM credibility in help to give information and marketing support to the apparel retailers. On the other hand, there are few of domestic study on the online WOM, leaving alone research on the actual situation of the apparel enterprise. The overseas research is not entirely accordance with the actual conditions in China, significantly different in cultural background and values of WOM. It is found that initiative to search information for WOM differentiate between Japan and the United States, due to Japanese more inclined to advocate collectivism, they are pro to more initiatively search for relevant information before making buying decisions. So for China, it is meaningful to take study on the credibility of online WOM of apparel enterprise.

\section{Reference review}

\subsection{Concept of WOM}

Earliest research on WOM verifies that WOM is the informal behavior between information transmitter and receiver in related to the evaluation of products or service through the way of face to face or others. WOM plays an important role in promoting new product. It is pointed out that WOM is the interpersonal communication resulted from consumer sharing experiences and evaluation of product. WOM is defined as the initiative information exchange between consumers about product specifications and using experience or service for non commercial purposes, including positive and negative information. It is considered that WOM has three characteristics: (1) WOM is the source of high degree of credibility. (2) WOM communication is a two-way flowing of information. (3) WOM communication is more vital and less intervened, which brings about high influence on consumers.

It is put forward that the elements of online WOM include: (1) The transmitter who initiatively posts views or evaluations of product or service online, or reprints and reposts the comments of others; (2) Information which could be searched and comprehended in form of digital document, file of text, voice, video and others which are posted online; (3) Media for broadcasting online WOM communication, by which online WOM is transmitted to receiver, such as virtual community, e-mail, chat rooms, etc.; (4) Receiver who initiatively searches or passively gets the WOM communication which take place between strangers, anonymities, forum members or acquaintances. 


\subsection{Relevant Review of Credibility}

Research on the credibility of individual transmitter features five fundamentally influential aspects which are: expertness, reliability, intentions, dynamism and personal attractiveness.

Credibility is conceptually divided into three aspects: (1) The credibility of online WOM source; (2) "Channel" defined as the virtual community for online WOM in form of post; (3) "The credibility of online WOM" regarding to the credibility, objectivity and comprehensibility of online WOM.

It is considered that the authority, reliability and professionalism of the website would affect the consumer credibility of online WOM. Tendency of consumer self-confidence is the factor that affects the credibility of WOM as well as purchasing intention of consumer. It is induced of three point of view: (1) Using of internet, reliance on internet, degree of information involved are significantly correlated to online credibility;(2) Convenience of Internet, using and reliance on traditional media are significantly correlated credibility of online news; (3) Gender and age of netizen are significantly correlated to the reliability on Internet.

\section{Structural Model}

\subsection{Previous Research Results}

Research model of how consumers recommend information mechanically influence consumer decision making tells that when going for hedonic shopping, with respect to professionalism, consumer is more inclined to be influenced by tie strength. When going for functional shopping, professionalism and tie strength are both in place. All independent variables affect trust which has an intermediary role between independent variables and dependent variable. Tendency toward self-confidence influences trust as well. Decision making process is directly affected by degree of involvement, prior knowledge, and difficulty of perceived task.

In-depth qualitative study on how online WOM communication impacts on consumers' evaluation and purchasing elaborates the effect of WOM communication on exchanging using experiences of product in the virtual community by applying social network theory. Website is introduced as a "nodes" in the network for studying how online WOM has an effect on consumer evaluation and purchasing. Based on previous study, structural model of online WOM credibility of apparel is proposed as Fig.1

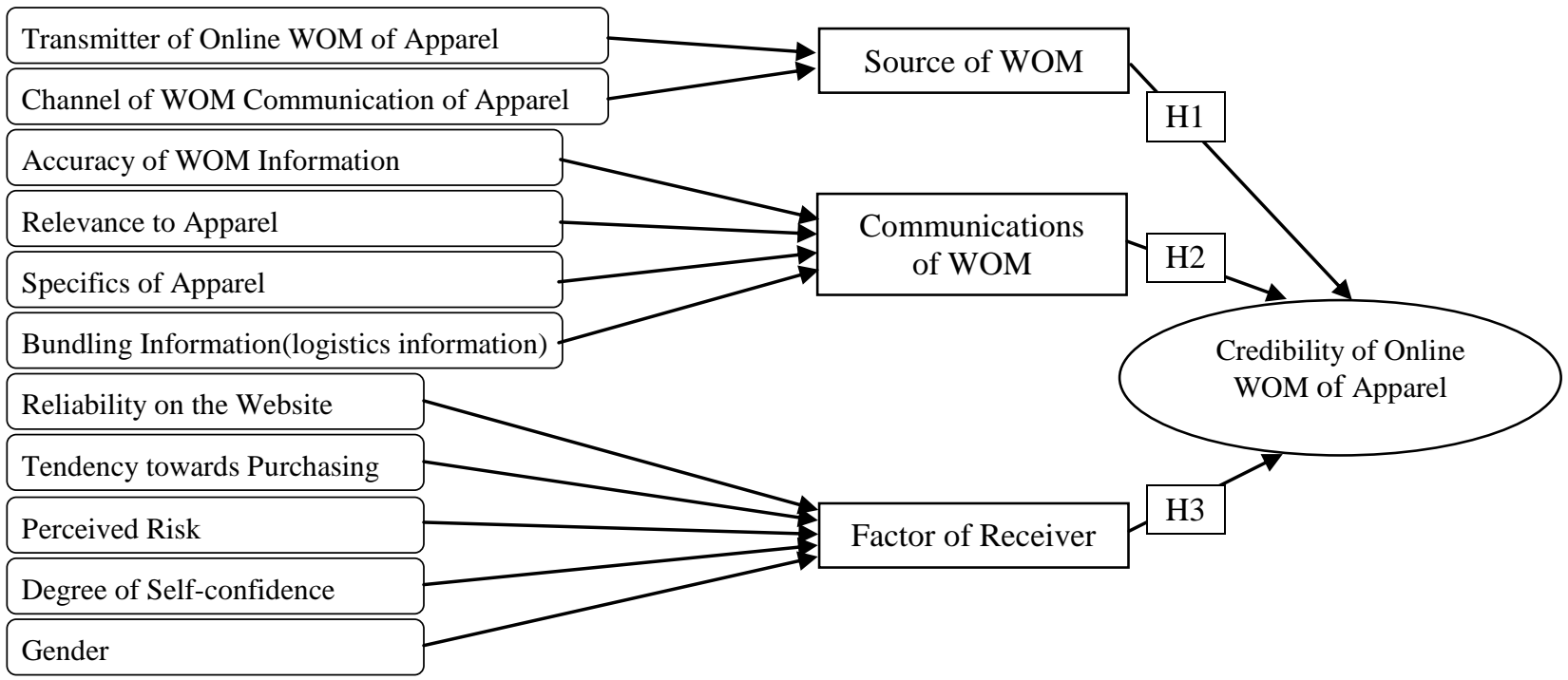

Fig. 1 Structure Model of Online WOM Credibility of Apparel

\subsection{Hypotheses}

Professionalism is defined as transmitter's ability of providing correct information that receiver perceives of. The professionalism of source of WOM brings up more convincing effect. By taking small scale pre-survey, we find there is almost no significant difference between transmitter and source of WOM in the apparel business, therefore in this paper, these two factors are attributed to the source of WOM. H1 is proposed:

H1: Source Credibility of online WOM of apparel has positive impact on that of online WOM.

Credibility of WOM communication encompasses the accuracy of WOM information, relevance to and the specifics of apparel, logistics information. $\mathrm{H} 2$ is proposed as:

$\mathrm{H} 2$ : Credibility of WOM communication of apparel has positive impact on that of online WOM

WOM is considered to be the information source to reduce perceived risk. The pragmatic research tells that using time, using experiences, reliability and gender of netizen are significantly correlated to the credibility of online WOM.

H3: Factor of receiver has positive impact on the credibility of online WOM. 


\section{Survey designed}

Questionnaire is the means for data collecting of the survey. Through literature review, small-scale pretest and revising the questionnaire, the influential factors of online WOM credibility of apparel are defined and measured. Apparel is divided into three levels of high, medium and low.

\subsection{Concept and Measuring of Variables}

Concept and measuring of variables in the paper are manifested in Table 1:

TABLE1. MEASURING OF VARIABLES

\begin{tabular}{|c|c|c|c|}
\hline $\begin{array}{l}\text { Name of } \\
\text { variables }\end{array}$ & Specific Indicators & Items & $\begin{array}{l}\text { Source of } \\
\text { Indicators }\end{array}$ \\
\hline $\begin{array}{l}\text { Source } \\
\text { credibility } \\
\text { of online } \\
\text { WOM }\end{array}$ & $\begin{array}{l}\text { Channel credibility } \\
\text { Source credibility }\end{array}$ & $\begin{array}{l}\text { I think the information provided by the website is useful } \\
\text { I think the information transmitter has affluent expertise and } \\
\text { knowledge on apparel } \\
\text { I think the information transmitter is objective } \\
\text { I think the information transmitter is reliable }\end{array}$ & $\begin{array}{l}\text { Voyer(1999) } \\
\text { Meyer(1988) }\end{array}$ \\
\hline $\begin{array}{l}\text { Credibility } \\
\text { of WOM } \\
\text { communica } \\
\text { tion }\end{array}$ & $\begin{array}{l}\text { Bundling } \\
\text { information(logistics) } \\
\text { Accuracy of WOM } \\
\text { information } \\
\text { Relevance to Apparel } \\
\text { Specifics of Apparel }\end{array}$ & $\begin{array}{l}\text { I think the information is precise } \\
\text { I think the comments highly related to apparel is more convincing } \\
\text { I think the comments including logistics information is more } \\
\text { convincing } \\
\text { I think the comments including logistics information in accordance } \\
\text { with my online shopping experiences is more convincing } \\
\text { I think the more specific information is, the more convincing }\end{array}$ & $\begin{array}{l}\text { Salwen(1987) } \\
\text { Invented by } \\
\text { author }\end{array}$ \\
\hline $\begin{array}{l}\text { Factor of } \\
\text { receiver }\end{array}$ & $\begin{array}{l}\text { Gender } \\
\text { Tendency of } \\
\text { self-confidence } \\
\text { Reliability on the website } \\
\text { Perceived risk } \\
\text { Tendency to shopping }\end{array}$ & $\begin{array}{l}\text { I think people in different gender has different belief in comments } \\
\text { I think most people worth of trusting } \\
\text { I think the comments on my familiar website is more } \\
\text { reliable } \\
\text { I think I have the perceivable ability of risk } \\
\text { I think the people intended to shop is more pro to believe the } \\
\text { commodity comments }\end{array}$ & $\begin{array}{l}\text { Smith(2002), } \\
\text { William H S, } \\
\text { KoufarisM } \\
(2005), \\
\text { Pavlou P A, } \\
\text { Fygenson M } \\
(2006)\end{array}$ \\
\hline
\end{tabular}

\subsection{Questionnaire Designed}

In the first part of the questionnaire, it is about to measure receiver's opinion toward online WOM source credibility of apparel, perceived WOM communication, and personal factors in terms of Likert scale. Second part is the basic personal information about respondents.

\subsection{Survey Methodology}

College students are respondents of the survey, owing to students have rich experiences of using Internet and shopping apparel as well as better perceivability of the evaluation of goods and spread of information. The data is collected through launching online questionnaire. 328 out of 346 pieces are valid, accounting for $95.9 \%$ of the total.

\section{Data analysis and model verification}

\subsection{Data Analysis}

The respondents acquire the information associated with apparel from Taobao, and other B2C, C2C websites, accounting for $55.7 \%$, much more frequent than other sources, while the professional apparel forum is the least frequent one with only $4.3 \%$. For the option of others, 8 person fill in recommendation from friends, which means this is also a more effective way to obtain information. $43.6 \%$ of the respondents are male, $56.4 \%$ female, exactly consistent with the reality that female online shopper dominates over male in terms of number.

The coefficient Cronbach's alpha is used to represent the reliability of the overall scale. Cronbach's alpha of this survey is 0.930 , which suggests that the overall reliability is better. Coefficient Cronbach's alpha for the 4 indicators of source credibility, WOM communication and factor of receiver respectively is $0.798,0.834$ and 0.804 , which suggests better reliability of the variables.

Validity is applied for checking out the validity of the questionnaire. This paper adopts exploratory factor analysis for testing the structural validity. First Kaiser-Meyer-Olkin measure of sampling adequacy and Bartlett's sphericity test are implemented before taking the factor analysis. Next, principal component analysis is used to extract the principal component factor. Through running process of the 14 items of online WOM credibility of apparel, three principal components are extracted, explaining $61.229 \%$ of the cumulative total variance.

\subsection{Results of Hypothesis Verified}

The verification of hypothesis is processed by regression model through the statistical software SPSS17.0. R square, also known as coefficient of determination, is in the use of determining degree of fitting linear regression. 
In the regression analysis of correlation between online WOM source credibility and online WOM credibility of apparel, $\mathrm{P}$ value is $0.000<0.01$, suggesting discrepancy is very significant. The correlation coefficient is 0.750 , meaning $\mathrm{H} 1$ is supported. See Table 2 and Table3.

TABLE2. TABLE MODEL SUMMARY

\begin{tabular}{|c|c|c|c|c|c|c|}
\hline & Model & $\mathrm{R}$ & R Square & Adjusted R Square & \multirow{2}{*}{\multicolumn{2}{|c|}{$\frac{\text { Std.Error of the Estimate }}{.714}$}} \\
\hline & 1 & $.750 \mathrm{a}$ & .563 & .560 & & \\
\hline \multicolumn{7}{|c|}{ TABLE3. COEFFICIENTS } \\
\hline \multirow{2}{*}{\multicolumn{2}{|c|}{ Model }} & \multicolumn{2}{|c|}{ Unstandardized Coefficients } & \multirow{2}{*}{$\begin{array}{c}\text { Standardized Coefficients } \\
\text { Beta }\end{array}$} & \multirow[b]{2}{*}{$\mathrm{t}$} & \multirow[b]{2}{*}{ Sig. } \\
\hline & & $\mathrm{B}$ & Std.Error & & & \\
\hline \multirow[b]{2}{*}{1} & Constant & 1.398 & .207 & & 6.763 & .000 \\
\hline & $3-6$ mean & .768 & .058 & .750 & 13.335 & .000 \\
\hline
\end{tabular}

a.Dependent Variable: WOM source

In the regression analysis of correlation between online WOM communication and online WOM credibility of apparel, $\mathrm{P}$ value is $0.000<0.01$, suggesting discrepancy is very significant. The correlation coefficient is 0.833 , meaning $\mathrm{H} 2$ is supported. In the regression analysis of correlation between factors of receiver and online WOM credibility of apparel, $\mathrm{P}$ value is $0.000<0.01$, suggesting discrepancy is very significant. The correlation coefficient is 0.777 , meaning H3 is supported.

Based on the above analysis, validation of the model data is shown in Fig.2. Online WOM communication is prior to other two elements factor of receiver and WOM source in affecting online WOM credibility of apparel. The path coefficient of structural model of on online WOM credibility of apparel is as followed:

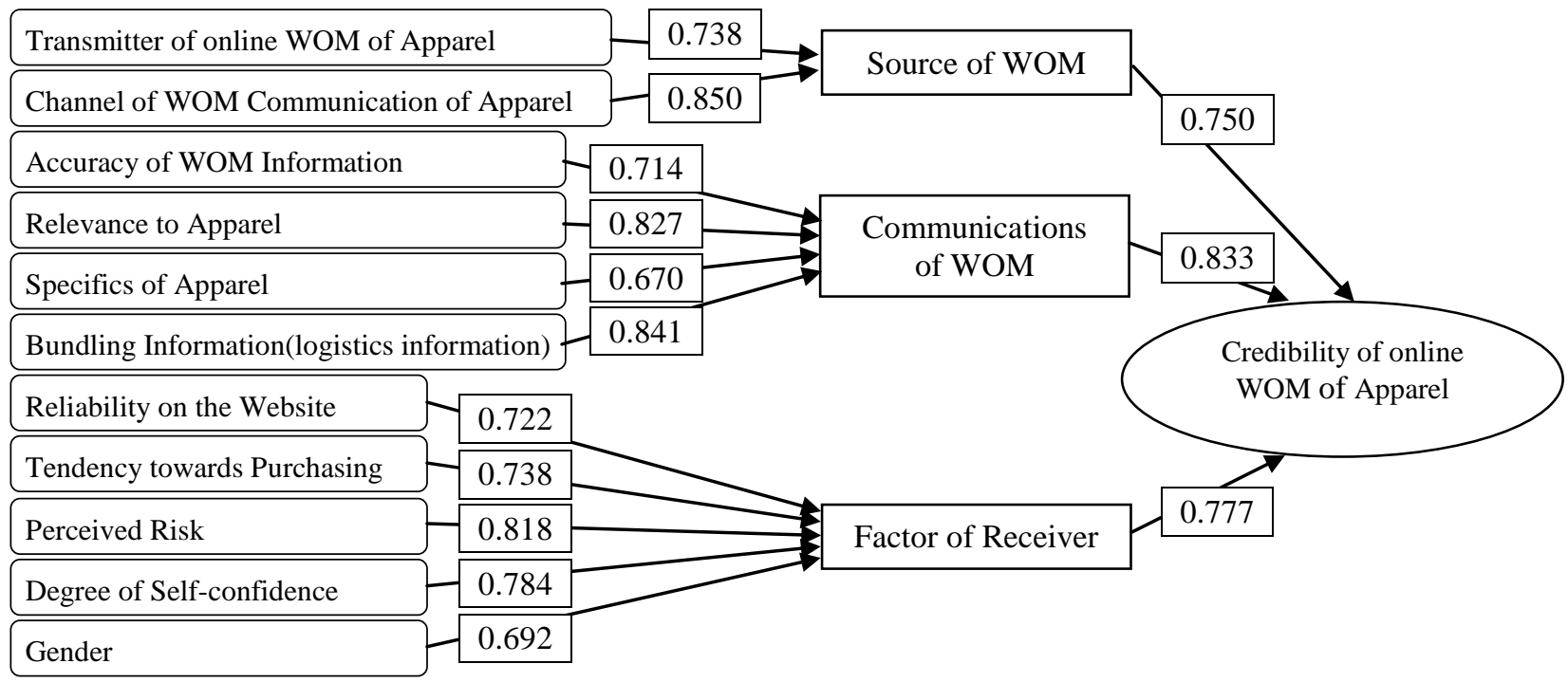

Fig.2. Path Coefficient of Structural Model of Online WOM Credibility of Apparel

\section{Conclusions}

Online WOM source of apparel has impact on receiver, meaning it is supposed to possess more professional knowledge and using experiences on apparel consequently leading to accumulate consumer credibility of apparel. WOM information should be as accurate and detailed as possible, more consistant with consumer demand. Apparel retailer should prompt interaction with consumers and encourage them to release their reviews on reliable website, paying more attention to the reviews consumers post on the third party professional comment platform which stand for justice and independence position. Apparel retailer should pave the way to make consumer perceive the marketing WOM by retailer actually comes from other user's authentic experiences, not for commercial purpose.

\section{Reference}

[1] Brown.J, Broderick A.J, Lee N, Word of mouth communication within online communities: conceptualizing the online social network. Journal of interactive marketing, 2007, 21(3): 2-20

[2] Giffin K, The Contribution of Studies of Source Credibility to a Theory of Interpersonal Trust in the Communication Process. Psychological Bulletin, 1967

[3] Meyer P, Defining and measuring credibility of newspapers: Developing an index. Journalism Quarterly, 1988, 65(3):567-573

[4] Money P, Reast J, Lynch J, Exploring the foundations of trust. Journal of Marketing Management, 1998, 14:159-172

[5] ZHANG Ming-xin, ZENG Xian-ming, Internet Use, Internet Reliance and Internet Information Cr edibility: A Case Study of the Internet Use Correlation in Wuhan, Journal of Hubei University(Philosophy and Social Science), 2007,34(3):111-115. 